\title{
The Passage From Death To Life: Paul's Notion Of Death With Christ In Romans 6
}

\author{
Teresa Kuo-Yu Tsui \\ National Chengchi University, Taiwan
}

\begin{abstract}
Paul in Romans speaks of a kind of death as the result of sin, which is also identified as spiritual death or the death of the soul. It is existence under sin, a state of lostness, a form of death despite biological vitality. Such existence is characterized by "living in the flesh" (7:5), as well as passions and immorality spoken of in Rom 1:18-32 and Rom 6-8. The remedy for spiritual death as existence in sin is the salvific death of Christ, which brings about "death to $\sin "(6: 2,10)$. It is by participation in the death of Christ that believers can be freed from sin (6:7), understood by Paul as a power $(6: 6,7,12)$ and an evil indwelling ruler $(7: 17,20)$, which compels one to do the evil that one does not want to do (7:19). Nowhere else in the NT is the death of Christ presented as a death to sin except in Rom 6, where Paul also speaks of believers' participation in the death of Christ (i.e., death with Christ) with various expressions: being baptized into his death (v. 3); being buried with him by baptism into death (v. 4); being united with the likeness of his death (v. 5); our old self being crucified with him (v. 6); having died with Christ (v. 8 ), whose death is a death to sin (v. 10). Believers' death with Christ as their death to sin, mediated by baptism $(6: 3)$, is significant in that it has overcome the dominion of $\sin (6: 14)$, destroy the body of $\sin (6: 6)$, free oneself from sin (6:7), and lead to a new life in Christ (6:4). This paper attempts to elucidate that "death with Christ" is indeed believers' passage from death to life, i.e., from spiritual death as existence in sin to spiritual life as being "dead to sin and alive to God" (6:11).
\end{abstract}




\section{Introduction}

The motif of Christ's death and the association of the Christian with this death are both prominent in Rom 6. Paul uses various expressions in Rom 6 to convey the notion of death with Christ: being baptized into his death (v. 3); being buried with him by baptism into death (v. 4); being united with the likeness of his death (v. 5); our old self being crucified with him (v. 6); having died with Christ (v. 8), whose death is a death to sin (v. 10). In describing the notion of death with Christ, Paul implies that Christ's death is salvific (Penna, 1996, p. 129). This is confirmed by the fact that Paul makes use of these expressions to articulate his thesis in v. 2: "we have died to sin." As a whole, Paul in Rom 6 suggests that in dying with Christ, believers have died to sin. As unfolded in the context of Rom 6, believers' death with Christ (or participation in Christ's death) brings about their own death to sin precisely because Christ's death itself is a death to $\sin$ (v. 10). As Moo points out, nowhere else in the NT is Christ's death presented as a death to $\sin ($ Moo, 1982, p. 219). The notion of death with Christ as death to sin in Rom 6 is unique in the NT.

That believers have died to sin means their existence in sin has been done away with. For Paul, existence in sin is a state of lostness, an ongoing death despite biological vitality. Death is referred to by Paul not only as physical death but also a manner of existence marked by sin, a way of "living" that is actually a form of death (De Boer, 1988, p. 75; Bultmann, 1967, p. 863; Grossouw, 1952, p. 32). In line with Paul, when commenting on Rom 6, Origen speaks of existence in sin as a kind of "spiritual death" or "the death of the soul," i.e., "that death in which the soul is separated from God by means of $\sin$ " (Commentary on the Epistle to the Romans Book 6-10). Origen specifies the death that sin confers is "the death of the soul," in which the soul is separated from God. This kind of death has more gravity than the death that separates the body from the soul. In Rom 7:7-25 Paul continues to describe the plight of existence in sin as an extreme form of immorality, resembling a type of moralpsychological death which can be identified as "the death of the soul" (Wasserman, 2008, pp. 7-8). Aside from Rom 7:7-25, Paul in Romans also characterizes "spiritual death" or "the death of the soul" as the result of sin in Rom 1:18-32 and in chapters 6 and 8, where sin is depicted as a threatening counterruler associated with the passions and the flesh.

William Loader, Boris Repschinski, Eric Wong (Eds.)

Matthew, Paul, and Others: Asian Perspectives on New Testament Themes

(C) 2019 innsbruck university press, ISBN 978-3-903187-66-5, DOI 10.15203/3187-66-5 
The remedy for believers to overcome spiritual death as existence in sin is their death with Christ, which Paul elaborates in Rom 6. In other words, believers' death with Christ is their passage from death (i.e., existence in sin) to life (i.e., new life unto God). In this paper, I will first explore the double references of death as well as Paul's logic of the passage from death to life in Rom 6. Second, I will demonstrate how Paul explicates "death with Christ" in Rom 6, especially with regard to vv. 6-7. Third, how Christ's death is conceived of in Rom 6 will also be examined.

\section{Paul's Logic of the Passage from Death to Life in Rom 6}

As stated above, existence in sin is nothing other than a form of death despite biological vitality, which is also identified as spiritual death. There can be discerned two kinds of spiritual death: negative and positive. Spiritual death as existence in $\sin$ is negative in contrast to another kind of spiritual death, i.e., death to sin, which is positive. Origen has distinguished two kinds of spiritual death in the context of Rom 6: (1) the death that comes through sin, which is also called the separation of the soul from God or the death of the soul; (2) a praiseworthy kind of death, namely, "that by which someone dies to sin and is buried together with Christ, through which correction comes to the soul and eternal life is attained;" "this is the kind of death that is given by God to confer life" (Commentary on the Epistle to the Romans Book 6-10). A contemporary commentator Templeton (1988) also noted such a double reference in Paul's use of death in Rom 6: (1) to a way of life that should be given up, and (2) to the giving up of that way of life. The condition of existence in sin as a kind of death should be replaced by the real life through giving up of the previous way of life. And this giving up of the previous way of life is undergone through death with Christ. This double reference in Paul's use of death in Rom 6 is also commented by Ashton: death is used to characterize life under sin since life as such is no proper life; it is dull, purposeless and empty. Death only takes on a positive meaning by negating the negation, that is, death to sin, since death to $\sin$ is death to death, and is therefore life (Ashton, 2000, p. 132).

To be free from existence in sin as a form of death, one has to die with Christ, whose salvific death has done away with sin's dominion. This is made clear in Rom 6:6-7. In v. 6 it is said that our old self was crucified and the body of sin destroyed, which signifies that sin's dominion has been annihilated in

William Loader, Boris Repschinski, Eric Wong (Eds.)

Matthew, Paul, and Others: Asian Perspectives on New Testament Themes

(C) 2019 innsbruck university press, ISBN 978-3-903187-66-5, DOI 10.15203/3187-66-5 
Christ's salvific death. The particle $\gamma$ ó $\rho$ links v. 7 to v. 6, affirming that the one who died - the one who died with Christ or participated in Christ's salvific death-has been freed from sin. The existence in sin or the old way, characterized in v. 6, is in contrast with the new life in Christ. The one who has been freed from sin (v. 7) is transposed to the new life in Christ.

As has been demonstrated, the gnomic quality of vv. 5,8 suggests that living with Christ ensues as a result of dying with Christ (Tsui, 2009). In other words, the gnomic future in vv. 5,8 renders dying with Christ and subsequently living with Christ as the logic of "the passage from death to life" in Rom 6. V. 4 also demonstrates such a logic: our new life unto God flows as a consequence of our sharing in Christ's death. The conjunction iv $\alpha$ in v. 4 introduces the purpose of our sharing in Christ's death, symbolized by the language of our burial with Christ into death. The purpose of our sharing in Christ's death is our walking in newness of life, which is ensured by the very fact that Christ was raised from the dead by the glory of the Father. As Jewett indicates, $̋ \sigma \pi \varepsilon \rho$... ovँ $\tau \varsigma$ is a correlative syntax, drawing "a parallel between the divine passive of Christ's being raised ( $\gamma \gamma \dot{\varepsilon} \rho \theta \eta)$ and the behavior of believers, which makes it clear that the latter no less than the former is a matter of divine causation" (Jewett, 2007,

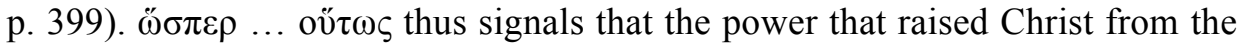
dead will also transpose us into the new life in Christ (Cranfield, 1975, p. 304; Käsemann, 1980, p. 166; Wilckens, 1987, p. 12).

Besides, the logic of the passage from death to life is also reflected in v. 8 ci

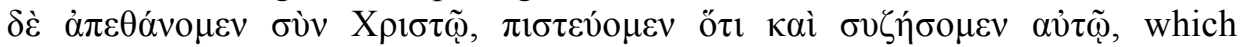
conveys the believers' dying with Christ and subsequently living with Christ. As Grundmann points out, "Rom 6:8 links dying with Christ indissolubly to Christ's death by putting [Christ's death] in a conditional clause and then stating [life with Christ] as a deduction from it" (Grundmann, 1971, p. 785). In a similar vein, Jewett indicates that "the apodosis draws the logical inference from the protasis of dying with Christ" (Jewett, 2007, p. 406). Moreover, Paul in v. 13 characterizes the believers as "those who have been brought from death

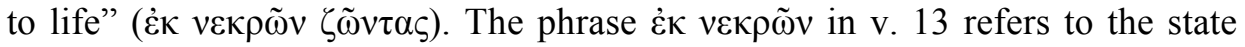
from which the believers must be saved, that is, a state of lostness, a former sinful existence, a state of death, which is replaced by life (Wedderburn, 1987,

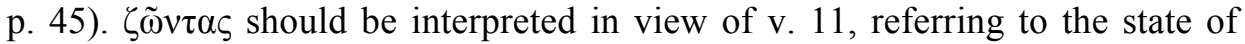
"being alive to God" of the believers in this present life (Moo, 1996, p. 386).

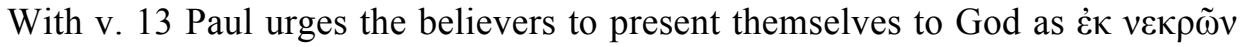

William Loader, Boris Repschinski, Eric Wong (Eds.)

Matthew, Paul, and Others: Asian Perspectives on New Testament Themes

(C) 2019 innsbruck university press, ISBN 978-3-903187-66-5, DOI 10.15203/3187-66-5 
$\zeta \tilde{\omega} v \tau \alpha \varsigma$, that is, as the living people brought out of their sinful past in which they were the dead.

Paul's logic of the passage from death to life indeed stands out in Rom 6 . Paul envisions that believers undergo the passage from death to life, that is, they leave behind the sinful existence that is equal to death, and subsequently enter the new life in Christ as a life to God. For believers, this passage of transformation from death to life is undergone through death with Christ or participation in Christ's death. As Ashton points out, Christ's death is "instrumental in the transformation of the Christian" (Ashton, 2000, p. 137). Christ's death is a death to sin (v. 10), and adherence to his death deprives sin of any power over human being (Schlier, 1977, p. 199; Wilckens, 1987, p. 19). In next section, we will further examine the meaning of death with Christ as death to sin with regard to Rom 6:6-7.

\section{Believers' Death with Christ as Death to Sin (Rom 6:6-7)}

Paul in Rom 6 relates the historical-soteriological fact of Christ's death to believers. First, he states his main thesis that believers have died to sin in v. 2 . He then shows a death has occurred on the part of believers in vv. 3-5, which is their death with Christ. From v. 6 onwards, he takes up the point that such a death is a death to sin and develops it fully in vv. 10-14. Thus, in Rom 6 believers' death with Christ has its reference to death to sin. Most commentators (Bornkamm, 1969, p. 75; Lamarche, 1980, p. 37; Wilckens, 1987, p. 18; Dunn, 1988, p. 305; Penna, 1996, p. 125) consider Rom 6:1-14 as a pericope, in which vv. 6-7 are taken to be the development concerning the fact of the death of Christ, and vv. 9-10 the development concerning the fact of the resurrection of Christ. It can thus be said that in vv. 6-7 Paul explains the effect of believers' "death with Christ," which I will explicate respectively as follows.

a. Our Old Self Crucified, the Body of Sin Destroyed (Rom 6:6)

Two phrases in Rom 6:6 require further explanations. First, in v. 6a $\dot{o}$

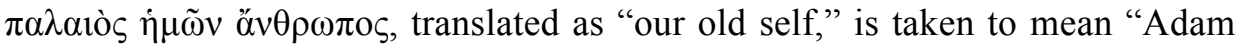
individualized and represented in us" (Barrett, 1975, p. 125), "the legacy of Adam that all persons share" (Cousar, 1990, p. 72), "existence in the old aeon, dominated by the baleful influence of Adam" (Byrne, 1996, p. 191). This "old person" under the dominion of the flesh - the power that keeps people away from the gospel and God-was crucified (Penna, 2007, p. 35). 
Second, in v. $6 \mathrm{~b}$ the iv $v \alpha$ clause is parallel to the preceding clause, so $\tau$ ò $\sigma \tilde{\omega} \mu \alpha$

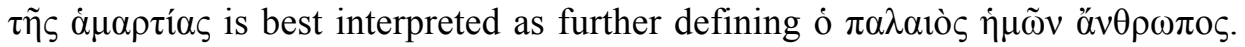

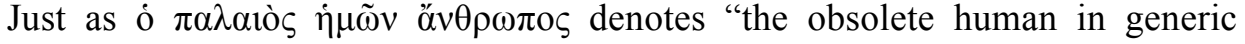
sense" (Jewett, 2007, p. 402) or "our old humanity" (Käsemann, 1980, p. 169),

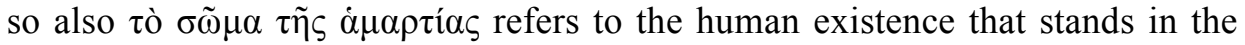
generic sense under the rule of sin and death (Käsemann, 1980, p. 161; Dunn, 1988 , p. 320; Jewett, 2007, p. 403). Both designate the humanity as a whole in the old existence, dominated by sin. As Tannehill observes, "these phrases do not refer to the 'old man' and 'body' of each individual, but to a collective entity which is destroyed in the death of Christ" (Tannehill, 1967, p. 24). Both o

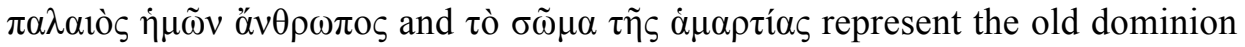
where sin and death reigned. This old dominion was broken by the obedient death of the eschatological Adam. The death of Christ accomplished a change in which the cosmic power of Adamic humanity was dethroned (Tannehill, 1967, p. 30; Cousar, 1990, p. 72).

The choice of the word $\sigma v \sigma \tau \alpha v \rho o ́ o \mu \alpha ı$ makes v. 6 a unique verse in Romans, where Paul recalls the idea of cross. Paul does not speak of Christ's death in a narrative way as a historical event or morally as in Mk 8:34. Rather, Christ's death in Paul's view is a participatory event: the co-crucifixion of the Christians consists in participation in the crucifixion of Christ as sharing in the soteriological effect of the crucifixion (cf. Col 2:14) (Penna, 2007, p. 35).

The co-crucifixion of the old self unfolds at two moments in the final clause introduced by iv $\alpha$, expressing the finality. The elimination of the body of $\sin$ is

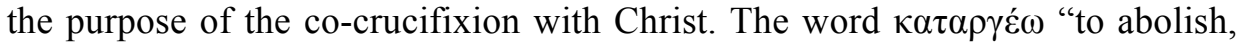
to wipe out, to bring to an end to," is typical of Paul (cf. Rom 3:3,31; 4:14, where this verb is applied with respect to the fidelity of God and the promise of Abraham). With $\kappa \alpha \tau \alpha \rho \gamma \varepsilon \dot{\varepsilon} \omega$, it is said as strongly as possible that the old existence, with the body tied to sin, is radically destroyed (Agersnap, 1999, p. 322). The infinitive construction in this final clause, which can be translated in English as a gerund: "for the purpose of our no longer being enslaved to sin" (Jewett, 2007, p. 404), further explicates the purpose of the co-crucifixion with Christ. The verb $\delta o v \lambda \varepsilon v$ suv indicates either a qualitative status (to be slaves) or active comportment conformed to this status (to live as a slave). As Penna notes, while in vv. 6-11 the former is connoted, the latter fits vv. 12-14 (Penna, 2007, p. 36).

b. The One Who Died Has Been Freed from Sin (Rom 6:7)

William Loader, Boris Repschinski, Eric Wong (Eds.)

Matthew, Paul, and Others: Asian Perspectives on New Testament Themes

(C) 2019 innsbruck university press, ISBN 978-3-903187-66-5, DOI 10.15203/3187-66-5 
The particle $\gamma$ ó $\rho$ in v. 7 indicates the connection with what precedes: v. 7 summarizes v. 6 with a maxim. Despite the attempts to identify Christ as o

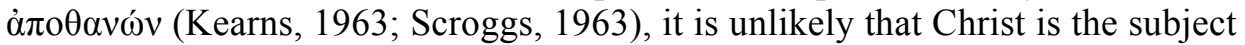
of v. 7 (Ziesler, 1972, p. 200; Cranfield, 1975, p. 310; Wilckens, 1987, p. 17; Stuhlmacher, 1989, p. 86; Penna, 1996, p. 129). As Schreiner (1998) indicates, "the context does not prepare us for a switch of subject from the believer in v. 6 to Christ in v. 7" (p. 319). Since vv. 3-4 the believers are said to die with Christ in baptism, v. 6 speaks of the believers' crucifixion with Christ, and v. 8 says "if we have died with Christ," the subject of v. 7 cannot, exceptionally, refer to Christ. Thus, ó $\alpha \pi \circ \theta \alpha v \omega$ v refers to the one who died in the way just described in the preceding verses. Klaar (1968) reminds us that the aorist o $\dot{\alpha} \pi \circ \theta \alpha v \omega ́ v$ is

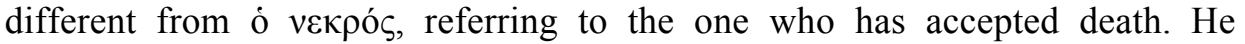
paraphrases Rom 6:7 as follows: "Denn der das...Sterben auf sich nahmperfektiv erledigt ist der Rechtsanspruch der Sündenmacht an ihm (auf weiteren Sklavendienst)" (Klaar, 1968, p. 134). The death that the one died is not a physical death but a death with Christ, a death metaphorically undergone (Morris, 1988, p. 253; Fitzmyer, 1993, p. 436; Penna, 2007, p. 37). In Cranfield's words, ó $\dot{\alpha} \pi 0 \theta \alpha v \omega$ v refers to "the man, who has died with Christ in God's gracious decision with regard to him, that is, who has died that death in God's sight to which his baptism points back and of which it is the sign and seal" (Cranfield, 1975, p. 311). Anyone who has died this way $\delta \varepsilon \delta 1 \kappa \alpha i ́ \omega \tau \alpha l ~ \alpha \dot{\pi o ̀ ~}$ $\tau \tilde{\eta} \varsigma \dot{\alpha} \mu \alpha \rho \tau i ́ \alpha \varsigma$.

As commentators point out, the rabbinic saying "once a man dies he is free from all obligations to fulfill the law" (cf. Shab. 30a, 151b) seems to echo in the background (Sanday and Headlam, 1899, p. 159; Michel, 1978, p. 131). If Paul does try to consciously echo with the rabbinic statement, v. 7 can mean that "“even physical death gives quittance from sin' (either because we are no longer in a condition in which it is possible to sin; or because death is the penalty of sin, and having paid the penalty we are exempt from any further claim against us)" (Kirk, 1947, p. 201). However, there is no certitude that Paul is consciously echoing the rabbinic statement. Moreover, there is certainly a major difference between the rabbinic statement and Paul's: here Paul speaks of the death with Christ, not the physical death at the end of natural life, as made plain by v. $8 \mathrm{a}$ (Ziesler, 1989, p. 161). Also, judging from Paul's use of the word $\delta \varepsilon \delta ı \alpha \alpha i \omega \tau \alpha 1$ with its specific theological sense, it is unlikely that Paul in v. 7 is simply repeating a rabbinic commonplace (Scroggs, 1963, p. 106; Cranefield, 1975, p.

William Loader, Boris Repschinski, Eric Wong (Eds.)

Matthew, Paul, and Others: Asian Perspectives on New Testament Themes

(C) 2019 innsbruck university press, ISBN 978-3-903187-66-5, DOI 10.15203/3187-66-5 
310; Käsemann, 1980, p. 170; Morris, 1988, p. 253). Moreover, the formulation in v. 7 affirms liberation not from the commandment but from sin. As Penna observes, even though Paul might have presupposed the Hebrew saying, v. 7 belongs to an original way of thinking. It is the context that gives the meaning to the verse (Penna, 2007, p. 37).

The detachment of v. 7 from the rabbinic saying as well as the specific theological sense of $\delta \varepsilon \delta 1 \kappa \alpha i \omega \tau \alpha$ in Paul lead commentators to construe

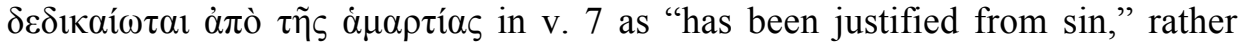
than "has been freed from sin" (Scroggs, 1963, p. 105; Cranefield, 1975, p. 311; Fitzmyer, 1993, p. 437; Morris, 1988, p. 253). But these two senses do not necessarily oppose to each other as the following two reasons will show. First, as Penna observes, in Rom 6:7 Paul uses $\dot{\alpha} \pi$ ó in conjunction with the verb $\delta$ iкaı́ $\omega$ rather than the usual preposition $\dot{\varepsilon} \xi$ (Rom $3: 20,26,30 ; 4: 2 ; 5: 1$; Gal $2: 16 ; 3: 8,24)$ or $\dot{\varepsilon} v$ (Rom $3: 4 ; 5: 9 ; 1$ Cor $4: 4 ; 6: 11$; Gal 2:17; 3:11; 5:4). It is to emphasize the distancing, liberating disconnection (Penna, 2007, p. 37). As such, the verb $\delta$ iкaió $\omega$ has a distinct significance apart from that which is habitual in Paul. In other words, apart from what Paul usually means with this verb, here Paul uses it with the sense of liberation from sin (Klaar, 1968, p. 134). Second, the more theological interpretation of the word $\delta$ iк set right, to be made righteous" is in fact not apart from the sense "to be freed from." As Jewett indicates, when it is placed in the framework that the death

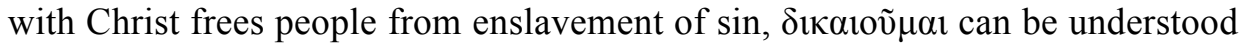
as being set free from the power of sin and thus being set right before God (Jewett, 2007, p. 405). In Ziesler's words, v. 7 can mean "he who has died (with Christ) is justified from sin"- - he is acquitted because the old self no longer exists and the verdict of being guilty cannot thus be passed. His interpretation combines the idea of "freedom from sin", as well as the notion of "being acquitted forensically and restored to the right relationship" (Ziesler, 1983, p. 200). Schreiner also notes that "righteousness necessarily involves freedom from the power of sin" (Schreiner, 1998, p. 319).

The idea here still goes beyond the justification/righteousness that is merely forensic. According to Penna, the perfect tense $\delta \varepsilon \delta 1 \kappa \alpha i \omega \tau \alpha$ expresses a radical innovation, transformation into a new situation, which derives from definitive liberation from sin (Penna, 2007, p. 37). Ziesler also sees this idea of justification intertwined with the notion of transferring from sin to a radical new situation. As Ziesler rightly observes, Paul's expression here is "so condensed

William Loader, Boris Repschinski, Eric Wong (Eds.)

Matthew, Paul, and Others: Asian Perspectives on New Testament Themes

(C) 2019 innsbruck university press, ISBN 978-3-903187-66-5, DOI 10.15203/3187-66-5 
as almost to be a mixing of metaphors" (Ziesler, 1989, p. 161). Paul's language of justification here is entwined with the language of transferring: to be set right before God means at the same time to be transferred from not being God's people in a state of guilt and powerlessness to being His people. "Those who have died with Christ are justified: nothing further is required of them. At the same time, to be justified and to die with Christ is to be released from one dominion and to enter another. It is to be released from sin and to enter the power of God in Christ" (Ziesler, 1989, p. 161). As such, v. 7 not only confirms v. 6 concerning the new freedom to resist the bondage of sin, but also expands v. 6 with the affirmation that such a new freedom comes from the fact that God has justified us from sin (Cranefield, 1975, p. 311; Morris, 1988, p. 253).

To summarize, believers' death with Christ that has already happened (which Paul stated in vv. 3-5) unfolds in vv. 6-7 as their death to sin: the old self crucified, the body of sin destroyed, so that they might no longer be enslaved to sin. And the one who died such death has been freed/justified from sin. Believers' death with Christ derives its significance from the soteriological meaning of Christ's death. It is thus important to reflect on how Paul conceives of the meaning of Christ's death with regard to Rom 6.

\section{The Meaning of Christ's Death in Rom 6}

As Dunn points out, the death of Jesus has two-fold significance in Paul's understanding: (1) Jesus died as a representative human in total identity with humans in their sinful flesh and fallenness so as to deal with sin in the flesh; (2) Jesus' death is a sacrifice for sin and signifies atonement (Dunn, 1974). Since Paul refers to Christ's death profusely in Rom 6, commentators speculate whether the notion of atonement is entailed therein. This is reflected in some commentators' interpretation of v. 7, which I will now examine closely.

a. Is the Notion of Atonement Involved in Rom 6 (esp. 6:7; cf. 6:2, 10)?

Some commentators (Sanday and Headlam, 1899; Grundmann, 1971; Morris, 1988) construe v. 7 to mean that the believer has been incorporated into Christ's atoning death and thus has been justified. As Scroggs indicates, "The believer participates in the death of the Righteous One and thus appropriates for himself the atonement for others which such a death achieves" (Scroggs, 1963, p. 108). Indeed, Rom 6:7 (cf. 1 Pet 4:1) can suggest the sense that "death pays all debts" in view of the NT thought concerning the death of Christ as paying the law its

William Loader, Boris Repschinski, Eric Wong (Eds.)

Matthew, Paul, and Others: Asian Perspectives on New Testament Themes

(C) 2019 innsbruck university press, ISBN 978-3-903187-66-5, DOI 10.15203/3187-66-5 
dues, or serving the full sentence. The maximum fine to sin is one's life; you cannot pay more than your life. Once you have parted with your life, you are quit. Hence Sanday and Headlam formulate their interpretation of Rom 6:7: "a dead man has his quittance from any claim that Sin can make against him" ((Sanday and Headlam, 1899, p. 159). As such, it echoes the rabbinic saying and implies that the believer, incorporated into Christ's atoning death, has served the ultimate sentence of death. And once the debt to $\sin$ is fully discharged, one is free from sin.

As Moule (1970) reminds us, though Rom 6:7 does not contain the dative construction, it has relevance to the expression "dying to sin" in Rom 6:2,10 (cf. "dying to the law" in Rom 7:4,6; Gal 2:19). All three verses concern the relation with regard to sin. Consequently the notion of atonement can apply to Rom $6: 2,10$, where the dative is then taken as the dative of obligation, which renders "dying to sin" as "meeting the penalties or sanctions for sin by the extreme cost of death" (p. 371). Such an interpretation can also stand in Rom 6 and 7.

However, in view of the context of Rom 7:1-6, Moule points out that it is more likely to construe the dative in Rom $6: 2,10$ as the dative of relation or reference. The dative of relation in the phrases "dying to sin" or "dying to the law" expresses the resulting condition of such death: non-existence so far as sin or law is concerned. The marital analogy (Rom 7:2-3) addresses our relation with the law, expressed by the dative, is "not that the demands of the law have been met with a costly death, but that we have been placed where the law no longer operates" (Moule, 1970, p. 372). In other words, so far as the law is concerned, or with reference to the law, our relation with the law has been annihilated, just as a woman's relation with her husband is legally annulled by death. This dative of relation can well be applied to the context of Rom 6, where Paul speaks of sin as a slave-master, to which we are to be freed from when the body of sin is destroyed through our death with Christ. It is more likely that in v. $7 \delta \varepsilon \delta 1 \kappa \alpha i \omega \tau \alpha$ means "has been vindicated against" rather than "acquitted in respect of (by payment of the dues)" (Moule, 1970, p. 374). In fact, Moule arrives at an interpretation that is similar to that of Ziesler and Schreiner as presented in the preceding section of this paper (II.b).

Admittedly, the possibility of an allusion to the clearing of the debt in Rom 6:7 cannot be totally ruled out. Rom 6:7 can thus mean "once you have died, you are vindicated against sin," to the extent that "there is no longer anything left for sin to get a grip of" (Moule, 1970, p. 374). The theological idea that the

William Loader, Boris Repschinski, Eric Wong (Eds.)

Matthew, Paul, and Others: Asian Perspectives on New Testament Themes

(C) 2019 innsbruck university press, ISBN 978-3-903187-66-5, DOI 10.15203/3187-66-5 
dative of obligation points to is indeed present in the NT. However, as Moule observes, it is not legitimate to read it into Rom 6:7 nor to press beyond this dative of relation to a dative of obligation (Moule, 1970, p. 375). Ultimately Moule is in favor of the dative of relation or reference since he does not think that Paul entertains the notion of atonement in Rom 6:7.

Moule's conclusion is most likely to be right. Cousar's observation (1990) confirms it. As he rightly points out, the meaning of Christ's death in Rom 6 is depicted as a participatory event (we died with Christ) rather than a vicarious substitution (Jesus in place of us). There is a change in soteriological categories in Romans (from substitution to participation), which appropriately parallels the change in the concepts of sin (from trespasses to ruling power). As can be observed in Romans, Paul speaks of Christ's salvific death as atonement for trespasses (Rom 3:22-25; 4:24-25; 5:6-9); only in chapter 6 does Paul shift to the language of participation in speaking of believers' death with Christ. These changes are also confirmed by the presence of the language of transference (i.e., the movement from one allegiance to another) in the context of Rom 6: the transference from the dominion of sin to that of God; the one who died is freed from sin and is exhorted to live to God and serve righteousness. Moreover, this soteriological idea of a change of allegiance is also present in Rom 7:1-6. Paul uses an analogy to explain how death breaks the loyalty to one party and establishes it with another. The transference lies in the believers' participation in the crucified body of Christ, which brings freedom from the oppression of the law and a liberating service for the one who was raised from the dead (7:6) (Cousar, 1990, p. 74). As the major thrust in Rom 6 and 7, the language of transference renders the dative as the dative of relation rather than the dative of obligation. The dative of relation in related verses in turn suggests that the notion of atonement is unlikely in play in Rom 6.

b. Christ's Death as a Participatory Event

In Romans, we witness a shift in Paul's understanding of Christ's death from substitution to participation, paralleled by the change in the concepts of sin: $\sin$ as trespasses atoned for by Christ's death (substitution) and sin as a power to be released from through death with Christ (participation). Paul does not entertain the idea of atonement in Rom 6, but instead he focuses on the notion of participation: through their death with Christ, believers died to the power of sin or to the old aeon, which results in their belonging to God; they are transferred from the dominion of sin to the lordship of Christ. As Sanders affirms, "[t]he

William Loader, Boris Repschinski, Eric Wong (Eds.)

Matthew, Paul, and Others: Asian Perspectives on New Testament Themes

(C) 2019 innsbruck university press, ISBN 978-3-903187-66-5, DOI 10.15203/3187-66-5 
transfer takes place by participation in Christ's death" (Sanders, 1977, p. 468, Italics his).

Indeed, Paul's understanding of Christ's death is that of "salvation through participation": "Christ shared all our experience, sin alone excepted, including death, in order that we, by virtue of our solidarity with him, might share his life" (Whiteley, 1964, p. 130). Christ as a representative human died "the death of the disobedient, of sinners" (Rom 5:6,8; 2 Cor 5:21) so that in his death we might share his overcoming of sin. Elsewhere Paul also expresses the same idea of participation. The most prominent case is 2 Cor 5:14: "one has died for all; therefore all have died." Here Christ's death "for all" is not primarily expiatory with the result that "all have had their sins expiated;" rather, "all have died." It is the category of participation that plays the prime role here. As Bassler observes, Paul's conclusion that "therefore all died" makes most sense if a mystical or participatory element is assumed in Paul's logic (Bassler, 2007, p. 42). Penna also recognizes that "there is an indispensable objective dimension to that death, at least in the sense that all without exception have come to participate in the sphere of influence of Christ's death as eschatological manifestation of God's saving power" (Penna, 1996, p. 133). In other words, 2 Cor 5:14, where there is an abrupt shift from "one died" to "therefore all died," should be explained on the basis of the view that in Christ Christians die with Christ to the power of sin, not simply that Christians have their trespasses atoned for (Tannehill, 1967, p. 66; Sanders, 1977, p. 465). Paul deepened "the idea of Christ's death as cleansing former trespasses so that it became the means by which one participated in Christ's death to the power of sin...it is clear that he did so, and that herein lies the heart of his soteriology and Christology" (Sanders, 1977, p. 453, Italics his).

It can thus be said that in Rom 6 the purpose of Christ's death is not so much as a means of expiation as a change of lordship: "that he might become Lord and thus save those who belong to him and are 'in' him" (Sanders, 1977, p. 465). As Ziesler also indicates, "Dying with Christ is the way to become in Christ, for the first concerns transfer from the old dominion, and the second concerns the consequent existence under the new power, Christ" (Ziesler, 1983, p. 97, Italics his). In guaranteeing such a new belonging to the lordship of Christ, the notion of participation has made the meaning of Christ's death in Rom 6 telling.

William Loader, Boris Repschinski, Eric Wong (Eds.)

Matthew, Paul, and Others: Asian Perspectives on New Testament Themes

(C) 2019 innsbruck university press, ISBN 978-3-903187-66-5, DOI 10.15203/3187-66-5 


\section{Conclusion}

The notion of death with Christ in Rom 6 indeed reveals the significance of Christ's death in Paul's thought. Departing from the early church's traditional view of Christ's death as atoning for sins, Paul in Rom 6 articulates the notion of participation in Christ's death. Believers' death with Christ brings about their own death to sin: the old self crucified, the body of sin destroyed, and freedom from sin. The spiritual death that is existence in sin may be overcome, and they may pass from death to life, i.e., from sinful existence as "death" to "life" as new life unto God. 


\section{Bibliography}

Agersnap, Søren. (1999). Baptism and the New Life: A Study of Romans 6,1-14, trans. Christine and Frederick Crowley. Aarhus, Denmark: Aarhus University Press.

Ashton, John. (2000). The Religion of Paul the Apostle. New Haven, CT, USA: Yale University.

Barrett, C. K. (1957). A Commentary on the Epistle to the Romans, Black's New Testament Commentaries. London, UK: Black.

Bassler, Jouette M. (2007). Navigating Paul: An Introduction to Key Theological Concepts. Louisville, KY, USA: Westminster John Knox Press.

Bornkamm, Günther. (1969). Baptism and New Life in Paul. In Paul L. Hammer (trans.), Early Christian Experience (pp. 71-86). London, UK: SCM.

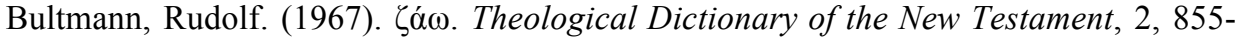
875.

Byrne, Brendan. (1996). Romans, Sacra Pagina, 6. Collegeville, USA: Liturgical Press.

Cousar, Charles B. (1990). A Theology of the Cross: The Death of Jesus in the Pauline Letters. Minneapolis, MI, USA: Fortress.

Cranfield, C. E. B. (1975). A Critical and Exegetical Commentary on the Epistle to the Romans, Vol. I, 6th ed., International Critical Commentary. Edinburgh, UK: Clark and Clark.

De Boer, Martinus C. (1988). The Defeat of Death: Apocalyptic Eschatology in 1 Corinthians 15 and Romans 5, Journal for the Study of the New Testament Supplement Series 22. Sheffield, UK: JSOT Press.

Dunn, James D. G. (1974). Paul's Understanding of the Death of Jesus. In Robert Banks (Eds.), Reconciliation and Hope: New Testament Essays on Atonement and Eschatology Presented to L. L. Morris on his 60 ${ }^{\text {th }}$ Birthday (pp. 125-141). Carlisle, UK: The Paternoster Press.

Dunn, James D. G. (1988). Romans 1-8, Word Biblical Commentary, 38. Waco, TX, USA: Word Books.

Fitzmyer, Joseph A. (1993). Romans, The Anchor Bible, 33. New York, NY, USA: Doubleday.

Grossouw, Willem Karel. (1952). In Christ: A Sketch of the Theology of St. Paul, trans. Martin W. Schoenberg. Westminster, UK: Newman.

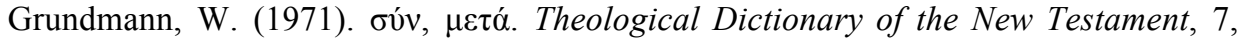
766-797.

Jewett, Robert. (2007). Romans: A Commentary, Hermeneia. Minneapolis, MI, USA: Fortress.

Käsemann, Ernst. (1980). Commentary on Romans, trans. Geoffrey W. Bromiley. Grand Rapids, MI, USA: Eerdman.

William Loader, Boris Repschinski, Eric Wong (Eds.)

Matthew, Paul, and Others: Asian Perspectives on New Testament Themes

(C) 2019 innsbruck university press, ISBN 978-3-903187-66-5, DOI 10.15203/3187-66-5 
Kearns, Conleth. (1963). The Interpretation of Romans 6:7. In Studiorum Paulinorum Congressus Internationalis Catholicus, Vol. I, Analecta Biblica, 17-18 (pp. 303-307). Rome, Italy: Biblical Institute.

Kirk, K. E. (1947). The Epistle to the Romans: In the Revised Version, with Introduction and Commentary. Oxford, UK: Clarendon.

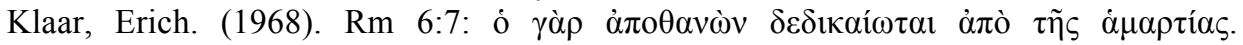
Zeitschrift für die neutestamentliche Wissenschaft, 59, 131-134.

Lamarche, P. (1980). Epître aux Romains V-VIII: Structure Littéraire et Sens. Paris, France: CNRS.

Michel, Otto. (1978). Der Brief an die Römer, 14. Aufl., Kritisch-exegetischer Kommentar über das Neue Testament, 4. Göttingen, Germany: Vandenhoeck und Ruprecht.

Moo, Douglas J. (1982). Exegetical Notes: Romans 6:1-14. Trinity Journal, 215-220.

Moo, Douglas J. (1996). The Epistle to the Romans, New International Commentary on New Testament. Grand Rapids, MI, USA: Eerdmans.

Morris, Leon. (1988). The Epistle to the Romans. Grand Rapids, MI, USA: Eerdmans.

Moule, C. F. D. (1970). Death 'to Sin', 'to Law', and 'to the World': A Note on Certain Datives. In Mélanges Bibliques en Hommage au R. P. Beda Rigaux (pp.367375). Gembloux, Belgian: Duculot.

Origen. Commentary on the Epistle to the Romans Book 6-10, The Fathers of the Church, Vol. 104, trans. Thomas P. Scheck. Washington, D.C., USA: Catholic University of America Press, 2002.

Penna, Romano. (1996). Baptism and Participation in the Death of Christ in Romans 6:1-11. In Thomas P. Wahl (trans.), Paul the Apostle, vol. I Jew and Greek Alike (pp. 124-141). Collegeville, MN, USA: The Liturgical Press.

Penna, Romano. (2007). Lettera ai Romani, vol. II, Scritti delle origini cristiane, 6. Rist.-Bologna, Italy: Dehoniane.

Sanday, William and Headlam, Arthur C. (1899). The Epistle to the Romans, 5th ed., International Critical Commentary. New York, NY, USA: Scribner.

Sanders, Ed Parish. (1977). Paul and Palestinian Judaism: A Comparison of Patterns of Religion. London, UK: SCM.

Schlier, Heinrich. (1977). Der Römerbrief, Herders theologischer Kommentar zum Neuen Testament, 6. Freiburg, Germany: Herder.

Schreiner, Thomas R. (1998). Romans, Baker Exegetical Commentary on the New Testament, 6. Grand Rapids, MI, USA: Baker Books.

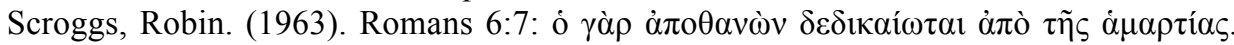
New Testament Studies ,10, 104-108.

Stuhlmacher, Peter. (1989). Der Brief an die Römer, Das Neue Testament Deutsch, 6. Göttingen, Germany: Vandenhoeck und Ruprecht.

William Loader, Boris Repschinski, Eric Wong (Eds.)

Matthew, Paul, and Others: Asian Perspectives on New Testament Themes

(C) 2019 innsbruck university press, ISBN 978-3-903187-66-5, DOI 10.15203/3187-66-5 
Tannehill, Robert C. (1967). Dying and Rising with Christ: A Study in Pauline Theology, Beihefte zur Zeitschrift für die neutestamentliche Wissenschaft und die Kunde der älteren Kirche, 32. Berlin, Germany: Töpelmann.

Templeton, D. A. (1988). Re-exploring Paul's Imagination. Eilsbrunn, Germany: Ko'amar.

Tsui, Teresa Kuo-Yu. (2009). Some Observations on the Use of the Future in Rom 6,5.8. Zeitschrift für die neutestamentliche Wissenschaft, 2, 289-297.

Wasserman, Emma. (2008). The Death of the Soul in Romans 7: Sin, Death, and the Law in Light of Hellenistic Moral Psychology. Tübingen, Germany: Mohr Siebeck.

Wedderburn, J. M. (1987). Baptism and Resurrection: Studies in Pauline Theology against its Greco-Roman Background, Wissenschaftliche Untersuchungen zum Neuen Testament, 44. Tübingen, Germany: Mohr Siebeck.

Whiteley, Denys E. H. (1964). The Theology of St. Paul. Oxford, UK: Blackwell.

Wilckens, Ulrich. (1987). Der Brief an die Römer, EKK 6/2. Köln, Germany: Benziger.

Ziesler, John A. (1972). The Meaning of Righteousness in Paul: A Linguistic and Theological Enquiry. Cambridge, UK: Cambridge University Press.

Ziesler, John A. (1983). Pauline Christianity. Oxford, UK: Oxford University Press.

Ziesler, John A. (1989). Paul's letter to the Romans. Philadelphia, PA, USA: Trinity Press. 